\title{
Investor Attention and Price Discovery Efficiency of Futures Market: The Role of Investor Structure
}

\author{
Shunping $\mathrm{Li}^{1}$ Lanqi Deng ${ }^{1, *}$ \\ ${ }^{1}$ School of Accounting, Yunnan Technology and Business University, Kunming, Yunnan \\ *Corresponding author. Email: denglanqi163@163.com
}

\begin{abstract}
With gradually increasing number of investors in futures market, the respondence of futures price to market information has been accelerated by more investor attention than former, which might improve the price discovery efficiency of futures market. Based on the monthly data of commodity futures in China from 2016 to 2020, this paper indicates the following findings. Firstly, as to Chinese commodity futures market, the greater investor attention improves price discovery efficiency significantly. Secondly, more participation of investors who trade for hedging restrains the relationship between investor attention and price discovery efficiency.
\end{abstract}

Keywords: Commodity Futures, Price Discovery Efficiency, Investor Attention, Investor Structure.

\section{INTRODUCTION}

With the high-speed development of commodity trading scale, futures market provides various financial instruments for hedging in field of commodity. This has brought a need to study the efficiency of futures market, and one of the important subjects is to research what influences the function of the price discovery of futures market. Historically, many scholars have committed to investigate whether the futures market is equipped to the function of price discovery, and the relationship between market structure and function of price discovery of futures market. In actually, however, the uncertainty of investors' behaviour is also a key factor which may arise the change of market characteristics. On the one hand, even now researchers could difficultly collect sufficient data to describe what investors do directly. On the other hand, because investors gradually depend on Internet to seek market information, it is feasible that researchers can use the data of online activities of investors recorded by Internet service provider to analysis investor behaviour.

In a general sense, the three major portals of the Internet include search engines, social network and shopping platform, the records of search activities of investors can more accurately reflect how investors pay close attention to the futures market comparing with the latter two. The prior studies have empirically examined the relationship between investor attention and price discovery efficiency of futures market by using the indirect proxy variable. However, few studies considered to measure the investor attention by the search volume, and the invest structure of futures market. To fill this research gap, this paper tries to the effect of investor attention on price discovery efficiency. Furthermore, the study also examines the facilitation or inhibition effects of investor structure on the relationship between investor attention on price discovery efficiency of futures market.

The rest of this paper proceeds as follows. In Section 2 , we describe the literature review and presents the hypotheses. In Section 3, we reveal the data and methodology, and present the baseline model for the interaction between investor attention on price discovery efficiency of futures market, and develop the moderating model for the investor structure. In Section 4, we show the empirical result of baseline model and moderating model. In Section 5, we overcome the endogeneity via sys-GMM estimator as the robustness test. Finally, Section 6 concludes.

\section{REVIEW OF LITERATURE}

\subsection{Price Discovery Efficiency of Futures Market}

According to market efficiency theory, there is no lead-lag relationship between futures price and spot price 
in perfectly efficient market. Actually, because of the trading cost, leverage and short selling, futures price often shows the function of price discovery on spot price, which is always considered as one of the most important economic function of futures market ${ }^{[1-4]}$. Since the 1990 s, there have been a lot of empirical studies on the price discovery function of futures market, which mainly focus on the stock index futures and foreign exchange futures due to that the high-frequency trading data is easy to collect ${ }^{[5-8]}$. Traditionally, the factors affecting price discovery efficiency are considered to be cost, leverage and liquidity ${ }^{[9]}$. Besides, from the perspectives of behavioural finance, some recent studies discussed how the price discovery efficiency of futures market is affected by investors and some other changes about investors, such as investor sentiment, news and macroeconomic environment ${ }^{[7,10]}$.

Generally, measuring the price discovery efficiency of futures market is often by the lead-lag relationship between futures price and spot price. The popular methods include Granger causality test, information share model, component share model and Garbade-Silber model, and it is worth noting that component share model and Garbade-Silber model is often used for quantitatively analysing the price discovery efficiency ${ }^{[11,12]}$.

\subsection{Investor Attention and Price Discovery Efficiency}

Based on the perspective of limited attention, investor attention is always defined the reason causing irrational exuberance ${ }^{[13]}$, which have been supported by many empirical studies. However, prior studies sought the indirect proxy variable to measure the investor attention including the number of headlines and ratings of financial TV programs ${ }^{[14]}$. With the development of Internet technology, recent studies used the search volume from the data service provided by search engines, such as Google Trends and Baidu Index, to measure investor attention directly ${ }^{[15,16]}$.

Differing from the stock market, increasing investor attention may not make the futures market efficiency, including price discovery efficiency, get worse. First, due to short selling and a lot of hedgers, more investor attention can decrease the crowd behavioural bias caused by herd behaviours. Moreover, more investor attention means more liquidity, which result to the futures price can reflect the market information in time. Thus, the study presents the following hypotheses:

H1: Investor attention has positive impact on price discovery efficiency of futures market.

\subsection{Investor Structure as a Moderator}

In the futures market, the trading motives of speculators and hedgers are different. Excessive speculators not only increase liquidity, but also increase irrational price volatility ${ }^{[17,18]}$, which weakens the price discovery efficiency of futures market. Then the increasing proportion of hedgers in the futures market increases can help to stabilize the futures price, and make futures price reflect the real expectation of the future price of the underlying assets, which helps to improve the price discovery efficiency of the futures market. Thus, the study presents the following hypotheses:

H2: Proportion of hedgers inhibits the relationship between investor attention and price discovery efficiency of futures market.

\section{DATA AND METHODOLOGY}

\subsection{Data and Sample}

The monthly data of the study over the period from 2016 to 2020 are selected from BaiduIndex.com, Wind and CSMAR. The sample of the study are 22 kinds of commodity in Shanghai Futures Exchange (SHFE), Dalian Commodity Exchange (DCE) and Zhengzhou Commodity Exchange (CZCE) and the study has totally 1320 observations.

\subsection{Dependent Variables}

The study uses the Garbade-Silver model to measure the price discovery efficiency of futures market, and the simultaneous equations is as follows:

$$
\begin{aligned}
& \Delta S_{t}=\alpha_{s}+\beta_{s}\left(F^{\prime}{ }_{t-1}-S_{t-1}\right)+e_{t}^{s} \\
& \Delta F^{\prime}{ }_{t}=\alpha_{f}+\beta_{f}\left(S_{t-1}-F^{\prime}{ }_{t-1}\right)+e_{t}^{f}
\end{aligned}
$$

The coefficient $\beta_{s}$ and $\beta_{f}$ is used to separately measure the role of futures price and spot price in price discovery. Thus, we can define the price discovery efficiency of futures market as:

$$
P D_{f}=\frac{\beta_{s}}{\beta_{s}+\beta_{f}}
$$

Obviously, the value of $P D_{f}$ is between 0 and 1 . If the futures market has the value of price discovery efficiency tended 0 , which implies the futures market has no function of price discovery. If the futures market has the value of price discovery efficiency tended 1, which implies spot price totally following futures price.

\subsection{Independent Variables}

The study employs the Baidu Search Index as the independent variable to measure investor attention, and this paper design independent variables from two different perspective. On the one hand, we collect the search volume with key word of commodity name, and use the natural logarithm of the search volume as the absolute indicator of investor attention; on the other hand, we divide the search volume with key word of commodity name by the search volume with key word of 
FUTURES, and use the ratio as the relative indicator of investor attention.

\subsection{Moderating Variables}

The study adopts the ratio of the registered warehouse receipt number to the total holdings of futures as the moderating variable to measure investor structure.

\subsection{Control Variables}

For controlling factors that may potentially affect the price discovery efficiency, the study adds four control variables of liquidity, position concentration, historical volatility and futures price into the estimation regression.

\subsection{Research Models}

For investigating the hypotheses $\mathrm{H} 1$, the study constructs a multiple linear regression model to examine the effect of investor attention on price discovery efficiency of futures market with controlling for four control variables, which show as following:

$$
\begin{aligned}
& P D_{i, t}=\alpha_{0}+\alpha_{1} \text { BSI }_{i, t}+\alpha_{2} \text { Liq }_{i, t}+\alpha_{3} \text { Pos }_{i, t}+ \\
& \alpha_{4} \text { Vola }_{i, t}+\alpha_{5} \text { Price }_{i, t}+v_{t}+\varepsilon_{i, t}
\end{aligned}
$$

Where, $B S I$ denotes the absolute indicator $B S I_{a}$ and relative indicator $B S I_{r}$, respectively.

For investigating the hypotheses $\mathrm{H} 2$, the study employs a moderator of investor structure to examine the inhabitation effect on the relationship between investor attention and price discovery efficiency of futures market with controlling for four control variables, which shows as following:

$$
\begin{aligned}
& P D_{i, t}=\alpha_{0}+\alpha_{1} B S I_{i, t}+\alpha_{2} I S_{i, t}+\alpha_{3} B_{S I} I_{i, t} \times \\
& I S_{i, t}+\alpha_{4} \text { Liq }_{i, t}+\alpha_{5} \operatorname{Pos}_{i, t}+\alpha_{6} \text { Vola }_{i, t}+ \\
& \alpha_{7} \text { Price }_{i, t}+v_{t}+\varepsilon_{i, t}
\end{aligned}
$$

\section{EMPIRICAL RESULTS}

\subsection{Description analysis}

Table 1 indicates that characteristics of all variables. Refer to dependent variable, PD is between 0 and 0.999 , and the standard deviation of PD is 0.304 , which means that the data distribution is large enough. Furthermore, $\mathrm{BSI}_{\mathrm{r}}$ is between 0.001 and 0.570 with lower-level value due to that the search volume with key word of FUTURES covers all kinds of commodity.

Table 1. Description Analysis

\begin{tabular}{l|l|l|l|l|l} 
Var & Obs. & Mean & Std. & Min & Max \\
\hline PD & 1,320 & 0.463 & 0.304 & 0.000 & 0.999 \\
\hline BSI $_{a}$ & 1,320 & 9.197 & 0.756 & 4.159 & 11.028 \\
\hline BSI $_{r}$ & 1,320 & 0.127 & 0.088 & 0.001 & 0.570 \\
\hline IS & 957 & 0.330 & 0.605 & 0.000 & 2.169 \\
\hline
\end{tabular}

\begin{tabular}{l|l|l|l|l|l}
\hline LIQ & 1,320 & 1.149 & 0.541 & 0.464 & 2.416 \\
\hline POSI & 1,320 & 0.268 & 0.095 & 0.084 & 0.637 \\
\hline VOLA & 1,320 & 0.219 & 0.097 & 0.093 & 0.443 \\
\hline PRICE & 1,320 & 0.778 & 0.619 & 0.001 & 3.665 \\
\hline
\end{tabular}

\subsection{Correlation Analysis}

Table 2 and Table 3 shows the correlation relationship of any two variables among all independent and control variables. These correlation coefficients of any two

\begin{tabular}{|c|c|c|c|}
\hline Corr. & $\mathrm{BSI}_{\mathrm{a}}$ & $B S I_{r}$ & IS \\
\hline$B S I_{r}$ & $0.796^{\star \star \star}$ & & \\
\hline IS & $0.055^{\star}$ & -0.043 & \\
\hline LIQ & $0.243^{\star \star \star}$ & $0.138^{* *}$ & -0.009 \\
\hline POSI & $-0.214^{\star \star \star}$ & $-0.280 * \star *$ & $-0.135^{\star \star *}$ \\
\hline VOLA & $0.291^{\star \star \star}$ & $0.144^{\star * \star}$ & $0.064^{\star \star}$ \\
\hline PRICE & $0.104^{\star * \star}$ & $0.078^{* \star *}$ & $-0.063^{*}$ \\
\hline
\end{tabular}
variables are less than 0.7 except $\mathrm{BSI}_{\mathrm{a}}$ and $\mathrm{BSI}_{\mathrm{r}}$, which indicates any one variable can individually explain dependent variable independently.

Table 2. Correlation Analysis

Note: * denotes significance at level of $10 \%$; ** denotes significance at level of $5 \%$; *** denotes significance at level of $1 \%$.

Table3. Correlation Analysis (continued)

\begin{tabular}{l|l|l|l}
\hline Corr. & LIQ & POSI & VOLA \\
\hline BSI & & & \\
\hline IS & & & \\
\hline LIQ & & & \\
\hline POSI & $0.063^{\star \star}$ & & \\
\hline VOLA & $0.634^{\star \star \star}$ & 0.025 & \\
\hline PRICE & $0.337^{\star \star \star}$ & $0.095^{\star \star \star}$ & $0.177^{\star \star \star}$ \\
\hline
\end{tabular}

Note: * denotes significance at level of $10 \%$;** denotes significance at level of $5 \%$; *** denotes significance at level of $1 \%$.

\subsection{Empirical Results}

The empirical results of the baseline estimation are shown in Table 4. According to the empirical results of Model 1 and Model 2, investor attention, measured with absolute indicator and relative indicator respectively, has a significant and positive effect on the price discovery efficiency of futures market, which supports the hypothesis $\mathrm{H} 1$.

Moreover, the empirical result also provides some evidence that support other prior studies. As for the control variables, the higher liquidity helps to increase the price discovery efficiency, and the volatility has a negative impact on the price discovery efficiency due to the noise traders. 
Table 4. Results of Baseline Estimation

\begin{tabular}{|c|c|c|}
\hline Var & Model 1 & Model 2 \\
\hline$B S I_{a}$ & $\begin{array}{c}0.064^{\star \star \star} \\
(0.020)\end{array}$ & \\
\hline $\mathrm{BSI}_{\mathrm{r}}$ & & $\begin{array}{c}0.414^{\star \star \star} \\
(0.149)\end{array}$ \\
\hline LIQ & $\begin{array}{c}0.055^{\star \star \star} \\
(0.016)\end{array}$ & $\begin{array}{c}0.063^{\star * \star} \\
(0.016)\end{array}$ \\
\hline POSI & $\begin{array}{l}0.505^{\star} \\
(0.264)\end{array}$ & $\begin{array}{l}0.505^{\star} \\
(0.264)\end{array}$ \\
\hline VOLA & $\begin{array}{c}-0.345^{\star * \star} \\
(0.103)\end{array}$ & $\begin{array}{c}-0.353^{\star \star \star} \\
(0.105)\end{array}$ \\
\hline PRICE & $\begin{array}{c}-0.028^{\star \star} \\
(0.014)\end{array}$ & $\begin{array}{c}-0.029 * * \\
(0.014)\end{array}$ \\
\hline cons & $\begin{array}{l}-0.285 \\
(0.190)\end{array}$ & $\begin{array}{l}0.233^{\star *} \\
(0.099)\end{array}$ \\
\hline Month Fixed & Yes & Yes \\
\hline Objects & 1,320 & 1,320 \\
\hline $\mathrm{F}$ & $147.92^{* * *}$ & $144.92^{* * *}$ \\
\hline$R^{2}$ & 0.108 & 0.106 \\
\hline
\end{tabular}

Note: $*$ denotes significance at level of $10 \%$; $* *$ denotes significance at level of $5 \%$; *** denotes significance at level of $1 \%$. Values in the parenthesis are standard errors.

Furthermore, the empirical results of the moderating estimation are shown in Table 5, and this paper omitted to report the coefficient of control variables for saving space. Firstly, as for the Model 1 and Model 3, only the moderator is added in the baseline model, which indicates that proportion of hedgers in futures market has a positive effect on price discovery efficiency. Secondly, the study adds the multiplicative interaction term for explaining the moderating effect. The empirical results of the study find that, when using the absolute indicator of investor attention, investor structure has no significantly moderating effect on the relationship between investor attention and price discovery efficiency of futures market. But investor structure significantly inhibits that relationship when the study measures the investor attention with relative indicator. Thus, the result partially supports hypotheses $\mathrm{H} 2$.

\section{ROBUSTNESS TEST}

In order to avoid the potential endogeneity of investor attention, this paper use sys-GMM to examine whether the price discovery efficiency of futures market has a positive effect on investor attention, which are showed in Table 6 . The empirical result of sys-GMM estimation is consistent with the results of OLS, although the coefficients are slightly different. Thus, the previous results are robust.
Table 5. Results of Moderating Estimation

\begin{tabular}{|c|c|c|c|c|}
\hline Var & Model 1 & Model 2 & Model 3 & Model 4 \\
\hline $\mathrm{BSI}_{\mathrm{a}}$ & $\begin{array}{l}0.034^{\star \star} \\
(0.015)\end{array}$ & $\begin{array}{l}0.038^{\star \star} \\
(0.015)\end{array}$ & & \\
\hline $\mathrm{BSI}_{\mathrm{r}}$ & & & $\begin{array}{l}0.411^{\star \star \star} \\
(0.130)\end{array}$ & $\begin{array}{c}0.458^{\star \star \star} \\
(0.133)\end{array}$ \\
\hline IS & $\begin{array}{l}0.019 * \\
(0.012)\end{array}$ & $\begin{array}{c}0.352 \\
(0.228)\end{array}$ & $\begin{array}{l}0.025^{\star \star} \\
(0.012)\end{array}$ & $\begin{array}{l}0.066^{\star \star} \\
(0.027)\end{array}$ \\
\hline IS_BSI & & $\begin{array}{l}-0.035 \\
(0.024) \\
\end{array}$ & & \\
\hline IS_BSI & & & & $\begin{array}{l}-0.311^{\star} \\
(0.184)\end{array}$ \\
\hline cons & $\begin{array}{l}-0.181 \\
(0.177) \\
\end{array}$ & $\begin{array}{l}-0.237 \\
(0.181)\end{array}$ & $\begin{array}{c}0.042 \\
(0.102) \\
\end{array}$ & $\begin{array}{c}0.014 \\
(0.104)\end{array}$ \\
\hline Controls & Yes & Yes & Yes & Yes \\
\hline $\begin{array}{l}\text { Month } \\
\text { Fixed }\end{array}$ & Yes & Yes & Yes & Yes \\
\hline Objects & 957 & 957 & 957 & 957 \\
\hline $\mathrm{F}$ & $94.65^{\star \star *}$ & $96.91^{\star \star \star}$ & $99.74^{\star \star \star}$ & $102.83^{* * *}$ \\
\hline$R^{2}$ & 0.113 & 0.115 & 0.111 & 0.114 \\
\hline
\end{tabular}

Note: * denotes significance at level of $10 \%$; ** denotes significance at level of 5\%; *** denotes significance at level of $1 \%$. Values in the parenthesis are standard errors.

Table 6. Results of sys-GMM Estimation

\begin{tabular}{l|c|c}
\hline Var & Model 1 & Model 2 \\
\hline BSI $_{a}$ & $\begin{array}{l}0.135^{\star *} \\
(0.060)\end{array}$ & \\
\hline BSI & & $\begin{array}{c}0.888^{\star *} \\
(0.354)\end{array}$ \\
\hline Controls & Yes & Yes \\
\hline Month Fixed & Yes & Yes \\
\hline Objects & 1,320 & 1,320 \\
\hline AR(1) & 0.000 & 0.000 \\
\hline AR(2) & 0.474 & 0.535 \\
\hline Sargan & 0.149 & 0.213 \\
\hline N
\end{tabular}

Note: $*$ denotes significance at level of $10 \%$; ** denotes significance at level of $5 \%$; *** denotes significance at level of $1 \%$. Values in the parenthesis are standard errors.

\section{CONCLUSION}

The purpose of this study is to investigate the effect of investor attention and the price discovery efficiency of futures market by using samples of 22 kinds of commodity in in SHFE, DCE and CZCE. The study also examines the moderating effect of investor structure on relationship between investor attention and price discovery efficiency of futures market. 
According to the empirical results, the study concludes that investor attention has a significant and positive impact on the price discovery efficiency of futures market, and proportion of hedgers have inhibiting effect on the relationship between investor attention and price discovery efficiency of futures market.

Based on the results of the study, the study would suggest that exchanges and brokers can increase investor attention, by advertising the futures investment, for improving the price discovery efficiency of futures market. Not only that, encouraging more hedgers to use futures for risk management helps to stabilize the futures market when a lot of noise traders bring exorbitant volatility.

\section{AUTHORS' CONTRIBUTIONS}

Shunping Li contributed significantly to the main conception, empirical analysis and manuscript preparation; Lanqi Deng performed the analysis with discussion and wrote the Section 1 and Section 2 of this paper.

\section{REFERENCES}

[1] Yang J, Bessler D A, Leatham D J. 2001. Asset storability and price discovery of commodity futures markets: A new look. Journal of Futures Markets, 21(3): 279-300.

[2] Chatrath A, Christie-David R, Dhanda K, Koch T. 2002. Index futures, leadership, basis behavior, and trader selectivity. Journal of Futures Markets, 22(7): 649-677.

[3] Yang J, Yang Z H, Zhou Y G. 2012. Intraday price discovery and volatility transmission in stock index and stock index futures markets: evidence from China. Journal of Futures Markets, 32(2): 99-121.

[4] Chen Y L, Tsai W C. 2017. Determinants of price discovery in the VIX futures market. Journal of Empirical Finance, 43(5): 59-73.

[5] Chan K A. 1992. Further Analysis of the Lead-Lag Relationship between the Cash Market and Stock Index Futures Market. Review of Financial Studies, 5(1): 123-151.

[6] Ghosh A. 1993. Cointegration and error correction models: Intertemporal causality between index and futures prices. Journal of Futures Markets, 13(2): 193-198.

[7] Chen Y L, Gau Y F. 2009. Tick sizes and relative rates of price discovery in stock, futures and options markets: evidence from the Taiwan stock exchange. Journal of Futures Markets, 29(1): 74-93.
[8] Wang Y Y, Chang C C, Lee W C. 2013. Price Discovery Between Regular and Mini Index Futures in The Taiwan Futures Exchange. International Review of Economics \& Finance, 27(3): 224-237.

[9] Frijns B, Gilbert A, Tourani-Rad A. 2015. The determinants of price discovery: Evidence from USCanadian cross-listed shares. Journal of Banking \& Finance, 59(10): 457-468.

[10] Fricke C, Menkhoff L. 2011. Does the "Bund" dominate price discovery in Euro bond futures? Examining information shares. Journal of Banking \& Finance, 35(5): 1057-1072.

[11] Booth G G, So R W, Tse Y. 1999. Price discovery in the German equity index derivatives markets. Journal of Futures Markets, 19(6): 619-643.

[12] Garbade K D, Silber W L. 1983. Cash Settlement of Futures Contracts: An Economic Analysis [J]. Journal of Futures Markets, 4(3): 451-472.

[13] Barber B M, Odean T. 2008. All That Glitters: The Effect of Attention and News on the Buying Behavior of Individual and Institutional Investors. Review of Financial Studies, 21(2): 785-818

[14] Chan W S. 2003. Stock price reaction to news and no-news: Drift and reversal after headline. Journal of Financial Economics, 70(2): 223-260.

[15] Da Z, Engelberg J, Gao P. 2011. In Search of Attention. The Journal of Finance, 65(5): 14611499.

[16] Yu Q J, Zhang B. 2012. Limited Attention and Stock Performance: An Empirical Study Using Baidu Index as the Proxy for Investor Attention. Journal of Financial Research, 8: 152-165.

[17] Bohl M T, Salm C A, Schuppli M. 2011. Price Discovery and Investor Structure in Stock Index Futures. Journal of Futures Markets, 31(3): 282-306.

[18] Basak S, Pavlova A. 2013. Asset Prices and Institutional Investors. American Economic Review, 103(8): 1728-1758. 